\title{
Political Elites and Politics of Exclusion as Challenges of Governance in Oyo State, Nigeria
}

\author{
Aliyu, M. Kolawole \\ Department of Political Science, \\ Obafemi Awolowo University, Ile - Ife, \\ Osun State, Nigeria \\ Ikedinma Hope Amoge \\ Department of Political Science, \\ Obafemi Awolowo University, Ile - Ife, \\ Osun State, Nigeria
}

Received: Jun. 22, 2021 Accepted: Jul. 14, $2021 \quad$ Online published: Sep. 14, 2021

doi:10.5296/jpag.v11i3.19005 URL: https://doi.org/10.5296/jpag.v11i3.19005

\begin{abstract}
This paper examined how political elites have excluded a number of people from partisan politics, and discussed the effect of the domineering role of political elites on good governance in Oyo state, Nigeria. The paper also examined the challenges that politics of exclusion pose on good governance in the study area. The study adopted primary and secondary data. For the primary data, in-depth interviews were conducted with ten purposively chosen respondents which comprised of former and serving lawmakers, party chairman, local government chairman, a labour leader, member of a social cultural group, and a serving commissioner. The secondary data was sourced from journal articles, books, newspapers and online publications. The primary and secondary data were content analyzed. The study found that political elites used the electorate to achieve their selfish political agenda; politics of exclusion is responsible for the poor participation of the people in partisan politics, undermining of democratic principles, and breeding of political violence in Oyo state, Nigeria. The study recommended that the Nigerian youths need to be more assertive to demand for accountability from political actors; while political elites should learn to do away with selfish interests. In addition, rule of law, freedom of the press and independence of the judiciary must be upheld in the country.
\end{abstract}


Keywords: elites, governance, politics of exclusion, inclusiveness, sponsor

\section{Introduction}

Politics of exclusion is still a major challenge to governance in Nigeria despite its growing embrace of democratic practice. It has affected good governance in terms of participation, consensus building, accountability, transparency, responsiveness, effectiveness, and inclusion of the majority in governance of the country. The practice of rotating political power from one clique to the other within the same social class negates principle of inclusiveness Instead of allowing more electorate involvement, popular participation in elections appears to have led to the emergence of leaders who pursue personal interest, and the interest of the minority who aided their emergence. The desperation for grab of power by political elites has led to emergence of political thugs who work for their sponsors and attack their sponsors' rivals, intimidate members of the public, rig elections, and protect their patrons from similar attacks (Obakhedo, 2011). In worst cases, some elites do everything possible to protect the interest of those that assisted them into power and neglect their main purpose of being in government; which is to represent the interest of the people.

Virtually in all political systems, elites have significant influence over more or less everything, except to give life (Bariledum and Serebe, 2013). According to Ekundayo (2017), the elites class, through decision making are capable of steering other sectors of the society, hence they play substantial role in national development. Thus, successful decision making and interpretation among the elite class are fundamental and crucial elements in national growth and development. In other words, power relations among the various elites reflected in the policy process (formulation and implementation), and on the long run; in the context of the country development. In more advanced nations, political elites constitute majority of the stakeholders that can facilitate effective governance and nation building (Adamolekun, 2013).

In all societies, whether technological or agrarian; governments have elites at the head. Elites constitute essential elements of the political and social life of the country. The stability of the state depends essentially on way in which the elites is organized and fits with the other sectors (Bariledum and Serebe, 2013). Nowadays in Nigeria, elites organize their kinsmen to make various demands on the State. Rather than coming together to transform the nation economically, elites mobilize their tribal forces to threaten national survival, and invariably distort governance (Okaneme, 2017). Thus, Nigeria's poor governance traits seem to have become more burdensome by the conducts of some of its elites. It is therefore obvious that Nigeria is grappling with the challenge of exclusionary politics. It can be inferred that Nigerian elites' conducts antagonize good governance, inclusiveness, accountability, transparency, responsiveness, effectiveness, equality, and the rule of law.

No doubt, democracy is an important ingredient of good governance, where the power to decide who to rule belongs to the people, and the power so exercised through their franchise. The decision as to who to govern a state lies within the entire citizens of a society. Therefore, inclusive politics is a good condition for the promotion of democratic governance (Baba, 2014). This implies that in a democratic state the elected leaders should represent the interest of the totality of the citizens and not a selected few. In a country where democratic dictates 
are low, the decision of the masses on who to govern does not count, only a few people make decision and the majority follows. Political elites have frustrated the process of governance in Nigeria and the practice is becoming a norm that threatens the survival of democracy. According to the vice president of Nigeria, Professor Yemi Osinbajo, political elites see wealth as a measure of worth and accounts for corruption among them such that even when they are not in power, they try as much as possible to install their persons in the corridor of power (Usman and Abba, 2017).

On daily basis, it appears politics in Nigeria is closed against non-elites. As a matter of fact, elite tendencies continue to be in pursuit of personal aggrandizement rather than altruistic policies (Arowolo and Aluko, 2012). In view of the growing influence of political elites on the occupation of political offices, this work examined how political elites have excluded many Nigerians from partisan politics in Oyo state, Nigeria and discussed the effect of the domineering role of political elites on good governance in the study area. The paper also examined the challenges that politics of exclusion pose on good governance in the study area. The specific objectives of this research are to:

i. find out how political elites cause politics of exclusion in Oyo state, Nigeria;

ii. find out how politics of exclusion affect good governance in the study area;

iii. investigate the effect of domineering role of political elites on good governance in Oyo state, Nigeria; and

iv. examine the challenges that political elites, and politics of exclusion pose on good governance in Oyo state, Nigeria.

To be able to achieve the above stated objectives, answers are to be provided to the following questions:

i. How do political elites cause politics of exclusion in Oyo state, Nigeria?

ii. How has politics of exclusion affected good governance in the study area?

iii. What are the effects of the domineering role of political elites on good governance in Oyo state, Nigeria?

iv. What are the challenges that political elites and politics of exclusion pose on good governance in Oyo state, Nigeria?

This study begins with a theoretical framework, using the elite theory. It is followed by conceptualizations in which elites, governance and politics of exclusion are defined and explained. The study is followed by a brief discussion of its methodology. Findings are later presented in sequence of the four research objectives stated above. They are also followed with a discussion segment in line with extant literature on the subject matter. Concluding remark is given to show the damaging consequences of the politics of exclusion by the political elites in Oyo state, Nigeria, and the steps required to be taken for the desired changes to be achieved.

\section{Theoretical Framework}

This study makes use of elite theory as its theoretical framework. The elite theory is a set of 
ideas, principles and assumptions on the concept, structure and exercise of power. It is a theory that interrogates power relationships in the modern society. The theory explains that a small group of people which can be found in the economic, educational, political, policy planning and military institutions of the state is vested with enormous power than the majority of the people. The theory is premised on two main sets of ideas. The first one is that power lies in position of authority in the hands of few key economic, political and military groups of people. The second is that the psychological difference that sets apart political elite from non-elite is that they have personal resources, for instance, intelligence, skills, and vested interest in government (Ekundayo, 2017).

Elite theory is of the opinion that a small minority consisting members of the economic elite, policy planning networks and military institutions hold power in any society. According to the theory, small group of people that wields enormous power is referred to as the political elite. It is a group of people with exceptional abilities in politics. In all societies, elite abounds and possesses exceptional ability to secure power, perpetuates it and rules (Friedrich, 2014 and Okonofua, 2013). Mosca cited in Ogundiya (2012) emphasized that political classes usually have certain material, intellectual or even moral superiority over those they govern. Vilfredo Pareto (1848-1923), an Italian Sociologist is regarded as major exponent of elite theory, contributed to the 'Theory of Elites and Circulation of Elites' in the book 'The Mind \& Society'. He applied socio-psychological factors to identify the elites and their nature.

According to Pareto, the degree of qualities differs from one person to another in every society. Also, in every civilized society only few persons have such inherent quality. In his opinion, "men are born unequal everywhere". They are also born physically and mentally unequal and these made their abilities and capacities to very". Thus, he made social stratification and class distinction on the basis of psychological traits such as 'superior class people as elites and the inferior one as non-elites'. He divides the society on the basis of necessary qualities and the function they undertake. He advises elites to possess certain qualities to remain or maintain themselves in power. Pareto has given prominence to 'Persistence of aggregates and Instinct of combinations' to maintain elite status in a civilized society. Pareto further divides the elite class in a civil society into governing and non-governing elites. He advocates inherent natural qualities and unequal distribution of residues in a civil society. On this basis, he proposed circulation of elites and nature of governing elites in a civil society.

Thus, the recruitment and the changing character of the Nigerian elite can be discussed in terms of Pareto's theory of circulation of elite. This theory refers to the process of movement in which individuals circulate between the elite and the non-elite. In Nigeria, for instance; the governing elites at national level are recruited not from the 'non-governing' elite at the same level but from the governing elite at state, local or ward level. These elite of lower political base are found holding important posts in state houses of assembly, political parties, and so on before becoming office holders at the higher political base. Once these elite rise from lower level to national level, they never go back to the old level but continue to function at the higher political level as long as they remain active in politics. 
According to Ojukwu and Shopeju, 2010, elites do not only control and dominate the economy, they exercise monopoly over the process of coercion, dominate the structures and institutions of politics and economy. They equally shape the ideological and philosophical direction of society. The political elites are present in every society, whether small or large, old or new. For instance, the power elite has been identified with those occupying key positions in the economic, political and military institutions in any country as in the United States of America. In the case of Nigeria, the economic, political and military powers are subsumed in the Hausa Fulani aristocracy and their collaborators from other ethnic groups (Ekundayo, 2017). With the aid of the elite theory, it is much easier and better to understand and appreciate the concept, structure and exercise of power in Nigeria and such other concepts as oligarchy, power brokers, mafia et cetera and their meanings, particularly in the Nigerian context. The elite theory as a framework will help to throwing more light on politics and other related concepts such as elite circulation, re-cycling of leaders and regime elongation or longevity in Nigeria. Elite theory makes it clear that those in power do not want to quit easily but to hold on to it tenaciously, whereas, some are also out there, struggling fiercely, to gain or hijack power. Elite theory is very relevant, particularly, in the area of political recruitment in Nigeria. This is so, as it has led to exclusion of the masses from participating in governance. This, therefore, explains the reason why the history as well as the process of political elite recruitment in Oyo state Nigeria has been one of a fierce struggle among politicians and political power seekers.

\section{Conceptualizations}

Elites are small persons who exercise disproportionate power and influence. According to Wikipedia (2015), political elite is a small group of people who controls a disproportionate amount of wealth or political power. This implies that political elites are the more powerful group of people in a political system. Scholars have different view of who political elites are; Blanda has called the political elite 'governing elite', Marx referred to them as 'ruling classes', Almond referred to those who monopolize power and rule the country as 'power elite', Riesman called them 'veto group', and Floyd Hunter called them 'top leaders'. According to C. Wright Mills, an American sociologist describes a relatively small, loosely knit group of people who tend to dominate American policy making. This group includes bureaucratic, corporate, intellectual, military, and government elites who control the principal institutions in the United State and whose opinions and actions influence the decisions of the policymakers. According the concept of Michel, mills, and Pareto political elite means the top minority that rules, struggles for power, takes decisions, and influences political conditions by their programmes and actions.

The definition of governance can be summed up as the continuous exercise of political authority over a political unit and it is related to a decision that defines expectations, grant power and verify performance. In essence therefore, governance is the total exercise of political authority and the use of institutional resources to manage societal problems and affairs. Governance is the process of decision-making and the process by which decisions are implemented or not implemented. According to (Omoregbe, 2007), both Plato and Aristotle agree that the purpose of the state is to provide man with what he needs to enable him live 
"the good life" and be happy. They both agree also that this is the purpose for which a government is formed. Plato does not see governance as something that anybody can just do. It is something which requires special training and education. It requires special training and education. Simply put, good governance is how public institutions conduct public affairs and manage public resources. It includes formulating policies, improving processes, implementing actions and ensuring stakeholders' involvement and participation in public affairs (Asemah and Okpanachi, 2013).

Politics of exclusion is about discrimination of the less privileged (the poor, the masses and the low profile people) from participating in governance not minding their capability. Political exclusion is defined as the share of the excluded population from representation in or influence over the political executive in the total population (Wimmer, Cederman and Min 2009). It would be correct to say that a number of the policies and actions of democratic governments in the world often run counter to the wishes and desires of a great majority of the people in the nation. This is because those policies and actions are adopted by the government and some lawmakers that comprise a relatively few people, thus exclusive of the inputs, preferences, and wishes of a large majority of the people. Political conflict, violence, rancor, and misunderstanding have also resulted from the exclusion of the people from decisions and choices of their government. People want to feel, surely, that they are involved in the decisions of the government, that their ideas and opinions matter and, if equality means anything, should be of the same weight as those at the helm of affairs who were elected by them. In short, people yearn to be included in government decisions that affect their lives. The politics of inclusion is what needs to be fully appreciated, recognized, and instituted, if democracy is worth practicing. This exclusion may stem from law, custom, intimidation or discrimination. Political exclusion by the law can be in diverse way; one of which is the constitution For instance, Chapter VI, Section 131B of the federal republic of Nigeria states that for a person to be qualified for election to the office of president, he must have attained the age of Forty (40) years thereby, excluding the youth compared to a country like France where the legal age is 18 years. By 'inclusion' it does not mean gender or ethnic or racial or immigrant groups in a nation that are or may be excluded from the political process rather, to ordinary citizens who have electoral and other political rights but have, nevertheless, been politically excluded or marginalized when it comes to the actual work of government, ordinary citizens whose voices have thus for a very long time been in the wilderness.

\section{Research Methodology}

This is a qualitative research that relied on primary and secondary data. Primary data was sourced through in-depth interviews while secondary data was sourced from newspapers, journal articles, books and internet-based materials. In all, a total number of ten persons were purposively selected for in-depth interviews which comprised of former and serving lawmakers, party chairman, local government chairman, member of the executive arm of government and social cultural group. The respondents from the political class were chosen from the two main political parties - All Progressive Congress (APC) and Peoples Democratic Party (PDP). The respondents were purposively chosen for in-depth interviews because of their involvement in partisan politics and relevance to issues of governance in Oyo 
state. Both the primary and secondary data were content analysed.

\section{Findings}

\section{How political elites cause politics of exclusion in Oyo state, Nigeria}

Several scholars, political actors, journalists, columnists, members of the civil society organizations and other relevant stakeholders have contributed to the debate on how political elites cause politics of exclusion in Nigeria. This study notes and acknowledges their diverse opinions. In an interview with Mr. Issa Aremu ${ }^{1}$, on how the political elites cause politics of exclusion in Oyo state, Nigeria, he opines that:

If you look at the elite theory you will find out that it posits that the people constitute the minority. This gives recourse to the statement made by late Chinua Achebe in his book titled: The Trouble with Nigeria; where he posits that the challenge with Nigeria is not about the environment or its geography but on leadership. Leadership in terms of governance lies solely on the elites. The collapse of the first republic and the second republic was based on the way and manner the elite conducted themselves in the then western region. The people have never been given the chance to decide their fate; rather it has been elites deciding for them. The implication therefore is that 90 per cent of the blame hangs around the elites.

The above view was also shared by Hon. (Mrs) Tolulope Akande-Sadipe ${ }^{2}$, who avers that:

The political elites believe in their selfish interest and not in an all- inclusive government. The elites in their usual nature manipulate the masses just to score cheap political points. The elites comprise the educated and wealthy ones who suppress the efforts of the masses. This suppression causes crises in politics in Oyo state.

Furthermore, Hon. Abdullahi Raji ${ }^{3}$ opines that:

The Political elites in their nature advance their personal interest over that of the masses. A case in point was the nature of President Olusegun who used his position to rig elections in the country while also trying to further a third term bid. Our democracy has gone past the teething stage and democracy is gradually been enshrined. In Lagos, politics of exclusion does not have a base because most ethnic are well represented in the parliament as well as in all ramifications.

Also, while reacting to the question posed by the researcher, Hon. Adebo Ogundoyin, Speaker of the Oyo State House of Assembly ${ }^{4}$ asserts that the elites are self-seeking and pursue ambitions that are detrimental to the state. According to him: 
The elites are selfish and pursue their parochial agenda. The elites, given their chauvinistic mindset; push the young folds aside and advance their own course. It plays out among the youths when very few get involve in partisan politics because political elites see political power as their birth right.

The views held by Issa Aremu, Hon. (Mrs) Tolulope Akande - Sadipe, Hon. Abdullahi Raji and Hon. Adebo Ogundoyin were supported by the positions held by Kai and Vurasi (2013) and Frank (1991) that the elite class in Nigeria seems to assume that it is unusual for all to decide development context. Analysis of contemporary situations in Nigeria reveals that the country elite class has no consistent and significant linkage to its national exploit given their quest to pursue their selfish interests. Frank (1991) posits that the formation and conduct of Nigeria's elite group have not been translated into a source of national development, despite the fact that powerful initiatives from within the elite groups is critically important for national development (Frank,1991). Consequently, Hon. Akin Alabi ${ }^{5}$ posits that:

Politics of exclusion breeds division due to the activities of the elites who are the supposedly enlightened class. It is in their nature to further their own plan of actions. This makes the polity heated up as it is currently witnessed generally in Nigeria.

Also, Chief Yinka Odumakin ${ }^{6}$ opines that:

The elites are those who constitute the minority, who lord over the majority. The reasons for their actions are simple: the pursuit of self over that of the generality of the people. This breeds chaos and as witnessed in time past in the country and Oyo state in particular.

Senator Tesleem Folarin ${ }^{7}$, while reacting to the question posed by the researcher opines that:

One of the challenges affecting our democracy is no doubt the politics of exclusion. In all, engaging in politics at the local level can nip this elite challenge in the bud. Of course the elites are always pursuing their interest by all means to the detriment of the state.

The above views were supported by the study conducted by Frank (1991) who posits that "the Nigeria elite class has had little disposition to contemplate the positive use of elite advantage as strategic instrument for engineering national development. Nigeria has realized very little of her potentials because of ineffective mobilization of these potentials by the elites. Today, the masses have limited access to education, good drinking water and adequate Medicare. According to Frank (1991), millions of Nigerians are said to be suffering from various deadly diseases. There is a prevalence of poor income and unemployment, street trading by children, hazardous reproductive behaviours". The position above was captured by Chief Akin $\mathrm{Oke}^{8}$ who asserts that: 
Everything in Nigeria revolves around leadership. For instance, the elites most times connect with their people or constituency when they carve their votes; immediately after elections they climb up to the position. Unfortunately, the masses do not know their rights, and so they allow themselves to be used as tools. There is a wide gap between the elites and the people.

Corroborating the above, former Senator Mulikat Sunmonu ${ }^{9}$ opines that:

The Nigerian political elite have allowed the country to go through degeneracy. A lot of despondency such that the youths of the country which constitute majority are frustrated, values have collapsed; and the security situation has gone beyond expectation. The purpose of government is to see to the welfare and security of the people. That is what philosophers of old spoke about several years ago. Unfortunately, the Nigerian elites have not been able to address these issues effectively. It has been argued by Kasimoglo and Robbinson that many countries in this clime are political and economic systems that thrive on exclusion.

The above positions were supported by Dr. Basiru V. Bello ${ }^{10}$ who asserts that:

The elites by definition consist of individuals who make up the minority in the society. They have distinct characteristics of pursuing their personal interest and the use of force. We all see these characteristics playing out in Oyo state today.

\section{Effect of politics of exclusion on good governance in the Study Area}

Politics of exclusion have a high number of degenerative tendencies on good governance in Nigeria. In the opinion of Issa Aremu ${ }^{1}$ while reacting to the above question acknowledges that:

Politics of exclusion especially within the domain of democracy is the brain behind thuggery, militancy and violence in many African States, including the intervention of the military in politics. What it means is that everybody is not given sense of belonging. This is the major challenge affecting the Nigerian State especially since 1999 . No doubt, inter-tribal and ethnic crisis in Nigeria are products of politics of exclusion. It has affected governance negatively because people pursue their selfish interest while in power. This contradicts democracy which should be all inclusive. The winner takes all in Nigeria politics is the major challenge affecting the state. Our electoral processes are heated because it is believed that 
whoever wins takes it all. Winner takes all mechanism since 1999 does not promote good governance. In democracy, it is often said that majority should have their way and minority have their say but politics of exclusion negates this philosophy.

Speaking along the same line, Hon. (Mrs) Tolulope Akande-Sadipe ${ }^{2}$ states that:

The effect of politics of exclusion on good governance is that political elites do not advance an all-inclusive government. This breeds the disagreement and chaos prevalent in the political space of the country.

Similarly, Hon. Adebo Ogundoyin ${ }^{4}$ while responding to the question posed by the researcher on the politics of exclusion opines that:

Politics of exclusion is destructive because it breeds mediocrity. Ethnicity and religion are the key pointers to politics of exclusion in the country. Exclusion advances incompetence over capability, and they are all hinged on ethnicity and religion.

The views of Braimoh were supported by Oloja (2016) who asserts that mediocrity over merit is a phenomenon secretly crippling the Nigerian State. It remains a social danger that has destroyed the Nigerian political space. In the same vein, Hon. Ogundoyin ${ }^{4}$ posits that:

Politics of exclusion in the country breeds mediocrity rather than merit. You see women and young men being relegated to the background all in the name of exclusion.

In his view, Chief Yinka Odumakin ${ }^{6}$ notes that:

The elites are scavengers who seeking personal interest turn the table around against the people. The elites back roll policies and restrict participation within them, which brings about bad governance and have a negative multiplier effect on the state.

While speaking on the effect from another perspective, Chief Akin Oke ${ }^{8}$ notes that things are not right with the country's democracy. According to him:

It is a misnomer as regards expectation of democracy that we have adopted. In the United States, for instance, an average politician uses two vehicles maximum, but here you will be surprised that a local government chairman has over four cars and a governor with over 16 cars, all in the name of being political elites.

On the other hand, Senator Mulikat Sunmonu ${ }^{9}$ avers that:

By the key principle of democracy which are accountability; 
mass participation; respect unto the rights of individuals, if government runs on exclusion, it no doubt runs against the gains of democracy. The elites have fostered a system of exclusion which has a way of weakening democracy. This is why some Nigerians sell their mandates because of economic woes.

Dr. Basiru V. Bello ${ }^{10}$ claims that good governance is the bedrock upon which any viable state thrives and is central to democracy. However, politics of exclusion heats up the polity. In his words:

Good governance is a feat desirable to countries that seek a conscious effort towards development. However, political exclusion is one of the major challenges affecting the Nigeria state, and more or less a major reason for agitation to rig election at all cost.

\section{Effect of the over domineering role of political elites on good governance in Oyo State}

In his view, Uroh (2004) provides a description of the Nigerian case in relation to how the over domineering role of the political elites have impacted on good governance in Nigeria. He notes that "many of the political parties operate more as instruments for the advancement of the selfish interests of powerful individuals in the state. It is influential individuals who often contest elections into political offices. Thus, elections have failed to empower the genuine representatives of the people. In an interview with Mr. Issa Aremu ${ }^{1}$, he claims that:

It is often said that he who pays the piper dictates the tune but the masses have become mere spectators. Although, the narrative is changing, yet political space is largely been influenced by political elites in Oyo state.

On the other hand, Hon. (Mrs) Tolulope Akande-Sadipe ${ }^{2}$ vividly captured the above in her response that:

The effect of the domineering role of the political elites is visible in the state systemic failure. Youths daily get involved in criminal activities and the likes because they are dissatisfied with the government.

The view of Agunsoye was corroborated by Usman and Abba (2010). They posit that in Nigeria, the stakes for power have been phenomenally high, often violent and mysterious, as exemplified by the nocturnal assassination like that of Chief Bola Ige, a serving Minister of Justice by hooded gunmen who stormed his residence in 2001, the murder of Sheikh Ja'afar Mahmood Adam, a Muslim spiritual leader with a populist following, on the eve of state elections in Kano; or the gruesome murder of Funsho Williams who at a time was vying for the position of governor in Lagos state. Violence appears to intensify and mystify the stakes for power (Usman and Abba, 2010). Similarly, Hon. Abdullahi Raji ${ }^{3}$ avers that: 
While the poor has been gradually wiped off in the scheme of things, what we have now are the super-rich and the middle class and their over domineering influence. The people (electorates) in most cases allow themselves to be oppressed because they want immediate satisfaction. Hence, I will blame the people for the domination by by the elites because they do not realize the power they have to remove any public office holder they are dissatisfied with.

On the other hand, Chief Akin Oke ${ }^{8}$ posits that:

The domineering influence of the elites on the masses can be traced to the constitution that gave too much power to the elite while relegating the people upon which democracy is built. There is need for a constitutional reform aimed at reducing the centralized nature of the country's elites and putting power in the people.

Senator Mulikat Sunmonu asserts that:

Attitudinal crisis is a challenge. Claude Ake once mentioned the contradiction of the Nigerian state trying to build democracy without democrats. The political elites are anti-democratic. You will recall a President who asserts that election was do or die for him. Another came out to say that the monkey and baboons will be sucked in blood if he doesn't win. These are pieces of evidence to show you that those who are suppose nurture the plants of democracy are the once that are undemocratic.

\section{Challenges political elites and politics of exclusion pose on good governance in Oyo State}

The challenges posed by the political elites on good governance in Nigeria are myriads. According Kia and Vurais (2013), today, political exclusion has become an ideology creating a power structure among Nigerians for desperate stealing of national resources. This dynamic is further reinforced by the relative economics prosperity associated with real or imagine favour derived from political advantage that accrue to group in control of public affairs in Nigeria. In an interview with Mr Issa Aremu1, he claims that:

The challenge of political elites in Nigeria is enormous. One of such challenge is not allowing the people participate in governance and decision making process. If we argue for direct democracy as practiced in the Ancient Greek City, It will mean that we all participate in governance. The votes of the electorates should be made to count. Also, there is need for re-awakening such that the people participate in Governance and voting people out of government. Karl Marx once said that the oppressor must be challenged by the oppressed through a 
revolution. I am of the opinion that we engage in a revolution, though not a bloody one. As $\backslash$ John Kalvin said: Democracy is an indisputable gift which centres on the people.

In his view, Hon. (Mrs) Tolulope Akande-Sadipe2 remarks that:

The challenges are multifaceted. The crisis we witness in Nigeria today which range from inter-tribal crisis, crimes like armed robbery all have an adverse effect on the Nigerian state, thereby making governance an impossible feat to achieve especially as there is absence of elite consensus.

The view of Agunsoye was corroborated by Usifo (2017), who noted that the high level of corruption witnessed in Nigeria impact negatively on the country. Political appointments are unevenly distributed and some states are not allowed access to control their resources. This somewhat justifies the militancy in the Niger Delta region which has witnessed the destruction of pipelines as well as the kidnap of oil workers. Furthermore, Hon. Abdullahi Raji ${ }^{3}$ avers that:

Politics of exclusion have a huge negative impact on good governance. If the people are dissatisfied with the government especially when they realize that their votes do not count, it makes good governance impossible in that the people see their representative as evil. This makes the state chaotic and stretched good governance.

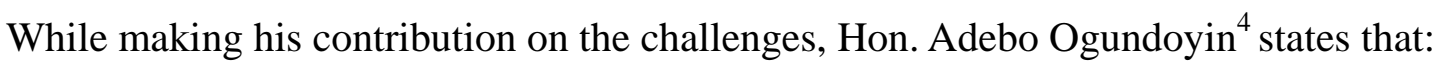

It advances mediocrity in good governance. A situation whereby certain positions are restricted to some persons due to their gender of age, it breeds bad governance because the wrong persons are found within the corridors of power

Also, Senator Tesleem Folarin ${ }^{7}$ reveals that:

The elites are the major cause of the crisis bedeviling the Nigerian political space. This is so because their activities further mediocrity and the resultant effect is the inter-ethnic and religious crisis we witness in the country.

In the views of Chief Akin Oke ${ }^{8}$ :

The challenges are four fold, it has led to the inability of the leadership of this country to provide good leadership, the county is underdeveloped, and they pursue their selfish interest. Also, they have failed to provide leadership in the country. 


\section{Discussion}

From the above findings, it can be deduced that political elites are self-seeking and pursue power by all means. This attitude undeniably makes entry into the elite circle impossible, especially, as they manipulate the masses, making them perpetually dependent on them - the political elites. Thus, the inordinate quest to hold on to power with the aim of furthering the selfish interests of the elites, made them to somewhat divide the people against ethnic lines. We can infer that the nature of the political elites to prevent some set of individuals from hijacking political power from them make them to hold on tenaciously to power. Thus in the process, the elites suppress the will of the electorates. This belief accounts for the use of the youths as political thugs to making troubles during successive electoral processes.

In addition, findings above equally suggest that politics of exclusion pose a threat to governance in Oyo state as evidenced in the misnomer attitudes in the political system. Rather than pursuing the interest of all, the political elites divide the polity across personal, political, and class lines which breed mistrust. Extant literatures corroborate the above views. For instance, Jide and Olumuyiwa (2015) posit that: the governing elite in Nigeria deriving from their social characteristics operate as a formidable team against the masses, who are encumbered with daily pressure for sustenance and necessities of life. The manipulative tendencies and tool by the elite inhibit genuine effort to advance common cause in form of qualitative education, shelter, basic infrastructure and other social amenities as deliverables of democratic governance. This in turn breeds violence in the state. Also, Madunagu (2005) validated this that "the dominant fraction of the Nigerian ruling class does not use the wealth they loot for the benefit of their people. The preference to looting of the nation's wealth reinforces the serial argument by scholars and public analysts that the governing elites in Nigeria are accomplices in plundering public resources

The findings from the study revealed that politics of exclusion is responsible for the various degree of anomalies witnessed in the country, such as the despotic nature of the political elites, as well as the over concentration of power on the centre leaving the regions as well as the people in perpetual dependence on the government. The political elites are interested in making the commoners to patronize them for things that should ordinarily be given to them without undue patronage. Also, the study revealed that politics of exclusion negatively affect governance in the country, in that the people are not allowed to participate fully in governance against the demands and tenets of democracy. In view of this, the system continues to breed mediocre.

Arising from the findings above, while good governance is a feat that most states are desirous of, the spate of politics of exclusion advanced by political elites undeniably tear the nation quest to develop apart. This results in crisis in most parts of the country especially in the north-east where lives are lost on a daily basis, pursuit for resource control and secession in the Niger-Delta and the South-East. It is also responsible for the decay in infrastructural facilities. The challenges political elites and politics of exclusion pose in Nigeria include ethnic violence and clashes, over concentration of power on few individuals, unemployment and low standard of living. No doubt, why socio-economic and political backwardness in the 
country is rising and political office holders continue to display rascality in governance.

\section{Concluding Remarks}

Political elites and politics of exclusion have impacted negatively on governance in Oyo state since the inception of the fourth republic, thereby breeding violence and undermining democratic principles. Given the findings of this study, the following recommendations are made. The youths in the state should rise up to their responsibility and demand accountability from their leaders. Youths across other states of the federation in Nigeria should be encouraged to do the same. Also, political elites should discard selfish interests and embrace a nationalist course that will bring about development. In addition, the call for political restructuring should be taken seriously in a way that excessive powers vested on political elites at the centre are devolved. Furthermore, the key tenets of democracy, such as rule of law, freedom of the press and independence of judiciary should be in the front burner of the state polity and governance. Quota system should be more faithfully implemented such that certain percentages of seats in the parliament are allocated to women and youths so as to increase their participation in partisan politics. To do this will require demonetizing contests into electoral positions.

\section{Endnotes}

1. Interview held with Mr. Issa Aremu, former Vice President, Nigeria Labour Congress, and member, National Institute, Kuru on $9^{\text {th }}$ November, 2019.

2. Interview held with Hon. (Mrs) Tolulope Akande-Sadipe (All Progressive Congress), member, House of Representatives, Oluyole Federal Constituency, Oyo State on $4^{\text {th }}$ December, 2019.

3. Interview held with Hon. Abdullahi Raji (Peoples Democratic Party), Chairman, Lagelu Local Government, Oyo State on $20^{\text {th }}$ February, 2020.

4. Interview held with Hon. Adebo Ogundoyin (Peoples Democratic Party), Ibarapa East and Speaker, Oyo State House of Assembly, on 10 ${ }^{\text {th }}$ December, 2019.

5. Interview held with Hon. Akin Alabi (All Progressive Congress) member, House of Representatives, Egbeda/Ona Ara Federal Constituency, Oyo State on $27^{\text {th }}$ January, 2020.

6. Interview held with Chief Yinka Odumakin, a Chieftain of the Afenifere Socio-Cultural Group in South West, Nigeria on $10^{\text {th }}$ September, 2019.

7. Interview conducted with Senator Tesleem Folarin, a two time senator and former Senate Leader representing Oyo South on $11^{\text {th }}$ February, 2020.

8. Interview conducted with Chief Akin Oke, Chairman, All Progressive Congress, Oyo State on $12^{\text {th }}$ October, 2019.

9. Interview conducted with former Senator, Alhaja Mulikat Sunmonu, All Progressive Congress, representing Oyo Central on $10^{\text {th }}$ December, 2019.

10. Interview conducted with Dr. Basiru V. Bello, former Permanent Secretary in Oyo state and Commissioner for Health on $10^{\text {th }}$ January, 2020. 


\section{References}

Adamolekun, D. K. (2013). The Challenges of Leadership and Governance in Nigeria in International. Journal of Academic Research in Business and Social Sciences, 2(9), 65 - 76.

Arowolo, L., \& Aluko, J. (2012). Political Elites and the Challenges of Nation Building in Nigeria. Global Journal of Politics, 8(2), 87 - 96.

Asemah, E. S., \& Okpanachi, R. (2013). Good Corporate Governance as a panacea for social problems in Nigeria. International Journal of Research in Multi-disciplinary Studies, 1(1), 97 $-112$.

Baba, I. (2014). Elites and Exclusive Politics in Sub-Saharan Africa. African Journal of Political Science and International Relations, 2, 89 -99.

Bariledum, Z., \& Serebe, O. (2013). Nigerian Elites as threat to Political Participation Since Independence. Canadian Social Science, 10(5), 210-220. http://dx.doi.org/10.3869/67420

Ekundayo, W. J. (2017). Political Elite Theory and Political Elite Recruitment in Nigeria. Public Policy and Administration Research, 7(5), 67 - 82.

Frank, P. (1991). The Mind and Society. New York: Harcount, Brace and Company.

Friedrich, D. Y. (2014). Shaping Nigeria's Elite Politics: The Imperative for Good Governance in Nigeria, London: The Macmillan.

Jide, C., \& Olumuyiwa, S. (2015). Ethnic Groups, Political Exclusion, and Domestic Terrorism, Defence and Peace Economics. Retrieved from https://www.researchgate.net/publication/274509538

Kai, B., \& Vurasi, S. S. (2013). The Political Elites and the Challenges of National Development: The Nigeria Experience. European Scientific Journal, 9, 34 - 46.

Madunagu, Z. (2005). The Sociology of Elite Domination. London: Palgrave Macmillan.

Obakhedo, N. (2011). Curbing Electoral Violence in Nigeria: The Imperative of Political Education. African Research Review, 5(5), 102 - 118. https://doi.org/10.4314/afrrev.v5i5.9

Ogundiya, L. (2012). The Nigerian Elites and the Crisis of Leadership. Uyo: Afahaide and Sons Publishers.

Ojukwu, C. C., \& Shopeju, J. O. (2010). Elite Corruption and the Culture of Primitive Accumulation in 21st Century Nigeria. International Journal of Peace and Developmental Studies, 1(2), $44-56$.

Okaneme, G. (2017). The Challenges of Leadership and Governance in Nigeria. Journal of Politics and International Affairs, 5, 113 - 128.

Okonofua, B. A. (2013). 'Who Rules Papa's Land? C. Wright Mills and the Nigeria Power Elites' SageOpen. Retrieved on 28th January, 2014 from URL:http://sgo.sagepub.com

Oloja, T. M. (2013). Nigerians are hungry and heavily burdened hungry! Retrieved from 


\section{Macrothink}

Journal of Public Administration and Governance

http://dailyindependentnig.com/2013/10/Nigerians-we're-still-hungry/

Omoregbe, P. (2007). Social-Political Philosophy and International Relations, Lagos: Joja Educational Research and Publishers Limited.

The Constitution of the Federal Republic of Nigeria (as amended).

Uroh, A. (2004). Governance and Leadership in Nigeria. Ibadan: Hope Publications Ltd.

Usifo, M. K. (2017). Political Participation and Democratic Practice in Nigeria. Global Journal of Human-Social Science: F Political Science, 14(8).

Usman, T., \& Abba, C. (2017). The Possibility of Collective Inclusion and Good Governance in Nigeria. Retrieved from http:www.businessdayonline.com/NG/index.php/news/111. Retrieved on 17th July, 2017

Wikipedia (2015). The Ruling Class and Elite Rule in Africa

Wimmer, H., Cederman, T., \& Min, J. (2009). .Elite Theory. Political Sociology, University of Texas at Austin Publications Ltd.

\section{Copyright Disclaimer}

Copyright for this article is retained by the author(s), with first publication rights granted to the journal.

This is an open-access article distributed under the terms and conditions of the Creative Commons Attribution license (http://creativecommons.org/licenses/by/4.0/). 